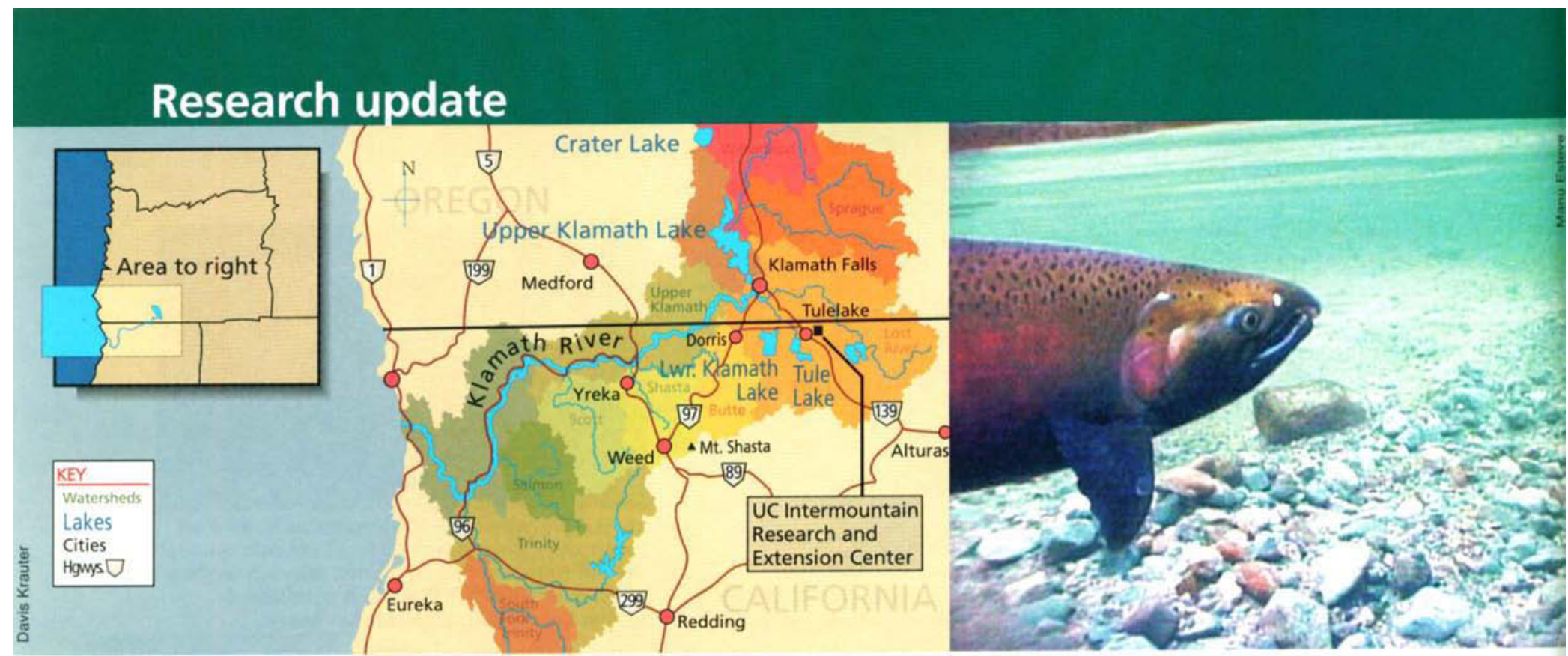

During a severe drought - and in response to a lawsuit by environmental groups and commercial fishermen - federal regulators cut off irrigation water to several hundred growers in the Klamath Basin, left, in April 2001, in part to maintain water flows on the Klamath River for imperiled coho salmon, right.

\title{
Lessons flow from Klamath Basin water crisis
}

W ater is flowing this summer, but the Klamath Basin continues to reel from the dramatic cutoff of irrigation water last year to hundreds of farmers.

Straddling the California-Oregon border, the high-elevation Klamath Basin is fairly remote and sparsely populated. But it made national headlines when a severe drought resulted in a decision by federal regulators on April 6, 2001, to stop the flow of irrigation waters that historically fed agriculture. The cutoff served to maintain flows in the Klamath River for coho salmon and to keep lake levels high for two endangered species of sucker fish in Upper Klamath Lake.

That's the day the phone started ringing off the hook at the UC Intermountain Research and Extension Center (IREC) in Tulelake, Calif., near the epicenter of the resulting uproar. On the other end of the line were desperate growers who needed answers on how to manage their dry fields, public agencies asking for information on improving irrigation efficiency, and scientists wondering whether they could conduct planned field studies.

"It was all consuming," says Harry Carlson, IREC superintendent and farm advisor. "The days were long." And more than year later, "it hasn't stopped," Carlson says, "although it's become a bit less intense."

UC scientists, advisors and outreach professionals continue to play a critical role in the Klamath Basin, providing science-based information, analysis and outreach for a variety of stakeholders, including farmers, fishermen, water managers, politicians, the media and government regulators.

At the same time, the IREC was dealing with a problem of its own: the cutoff of water to the 100- acre research plot leased for several decades from the Tulelake National Wildlife Refuge (see box).

The research program is on track this year, but Carlson estimates that he still spends half his time on activities related to last summer's irrigation cutoff, including serving on several regional committees and task forces. "We're looking at more long-term solutions," Carlson says. "If there's a silver lining to what happened, it's that there is almost a consensus across the stakeholders that we don't ever want to do it the way we did last year."

\section{Century-old conflict}

Last year's crisis has its roots in the century-old Klamath Project. In 1905, the federal government began draining much of the region's vast wetlands in order to create rich farmland. The land was offered to veterans of World Wars I and II, who were the nation's last "homesteaders" in the lower 48 states. The Basin's farmers today grow potato, alfalfa, horseradish and other crops, and raise livestock.

Six National Wildlife Refuges were also established in the Klamath Basin, which shelter millions of birds migrating along the Pacific Flyway and the largest wintering population of bald eagles in the continental United States. Nonetheless, coho salmon on the 254-mile Klamath River, as on many other Northwestern rivers, now face extinction. Two species of lake fish -- which $\mathrm{Na}$ tive Americans had relied upon as a food source for centuries - are on the federal endangered species list: the Lost River sucker and the shortnose sucker.

With agricultural drainage providing much of the water for the wildlife refuges, "the connection between farming and the refuges is quite strik- 
ing," says UC Davis agronomist Steve Kaffka.

For the past century, farmers, commercial fishermen, Native Americans, and wildlife and environmental activists have clashed over water, although the needs of agriculture were met most consistently. A drought in 1992 affected water deliveries to agriculture and initiated "the era of meetings and lawsuits," Kaffka says.

During the severe 2001 drought, the region received about half of its normal rainfall. A consortium of commercial fishermen and environmental groups sued the U.S. Bureau of Reclamation to limit water deliveries to farmers. Responding to the lawsuit and biological opinions issued by the U.S. Fish and Wildlife Service (FWS) and U.S. National Marine Fisheries Service (NMFS), the Bureau cut off irrigation water to most project growers to protect the fish.

While a subsequent moderately wet winter has eased the drought, environmental, tribal and fishing organizations have continued their legal efforts to maintain increased river flows and lake levels for fish. Faced with certain water shortages in the future, the situation remains tense.

\section{Research informs Basin}

Research is helping to provide critical information that the region needs to farm more efficiently and conserve and protect natural resources. Currently two dozen research projects are under way at the IREC, ranging from studies to develop improved potato, grain and alfalfa varieties to efforts to improve irrigation and pest management.

Water quality. For the past several years, Kaffka has been evaluating the effects of farming on water quality in the Klamath Basin, including surveying historic data to provide a baseline for comparison with more recent assessments. His team collected water samples every 10 days for several years, at 28 sites where water moves in and out of the Tulelake Irrigation District. Combined with earlier sampling efforts, they are now analyzing approximately 5,000 data points, the largest such data set ever collected in the region. "The data will be used to develop TMDL (total maximum daily load) rules for the Klamath River," Kaffka says.

Pasture and alfalfa irrigation. Steve Orloff, Siskiyou county director and farm advisor, and colleagues completed research in the late 1990s on the relationship among alfalfa and pasture irrigation, low flows in the Scott River and declines in anadromous fish populations. They found that there was potential to reduce irrigation, particularly on pastures, providing some potential for water conservation. Researchers are continuing to study the effect of the early-season irrigation cutoff on alfalfa yields. "Growers were surprised at how much yield they had with no water allocation," Orloff says.

\section{Science peer review}

In addition to conducting research, UC scientists have played an important role in reviewing the scientific foundations of government regulatory decisions. "UC scientists were brought in by outside people to take an objective look

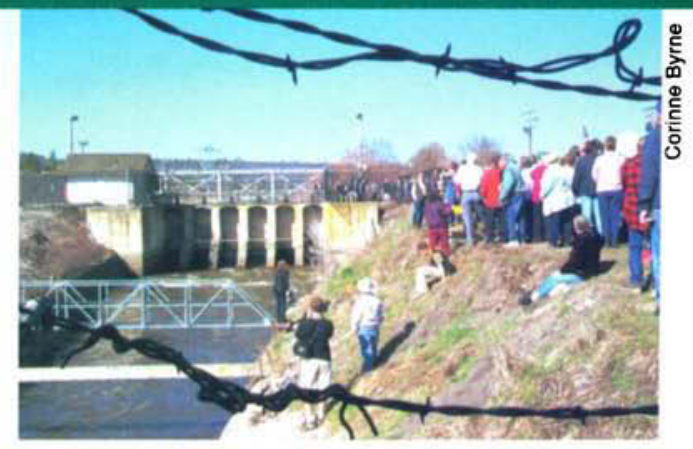

On March 29, 2002, the headgates at Canal A in Klamath Falls, Ore., were opened to provide irrigation water for Klamath Project farmers. Coastal commercial fishermen subsequently filed a lawsuit to maintain adequate flows on the Klamath River for migrating coho salmon. at the science and ask the hard questions, and see if the evidence was there to support various viewpoints," says UC Davis fish biologist Peter Moyle.

ANR peer review. In June 2001, state Assemblyman Dick Dickerson (R-Redding) asked the UC Division of Agriculture and Natural Resources (ANR) to peer review the FWS biological opinion on endangered suckers. The review, by four anonymous scientists, found that the science upon which the opinion was based was inadequate, but that the service did the best job it could with the information available.

NAS report. In February 2002, the National Academy of Sciences (NAS) released an interim scientific evaluation of the FWS and NMFS biological opinions on the Klamath Basin's imperiled fish. While not directly questioning the decision to maintain minimum water levels at Upper Klamath Lake, the scientists found that the FWS data upon which that decision was made was not adequate.

"Based on existing evidence, the case wasn't strong at all," says Moyle, who represented UC on the NAS review committee along with UC Davis geologist Jeffrey Mount.

At the same time, the committee found that increasing flows to the Klamath River's main stem, as recommended by NMFS, probably would not

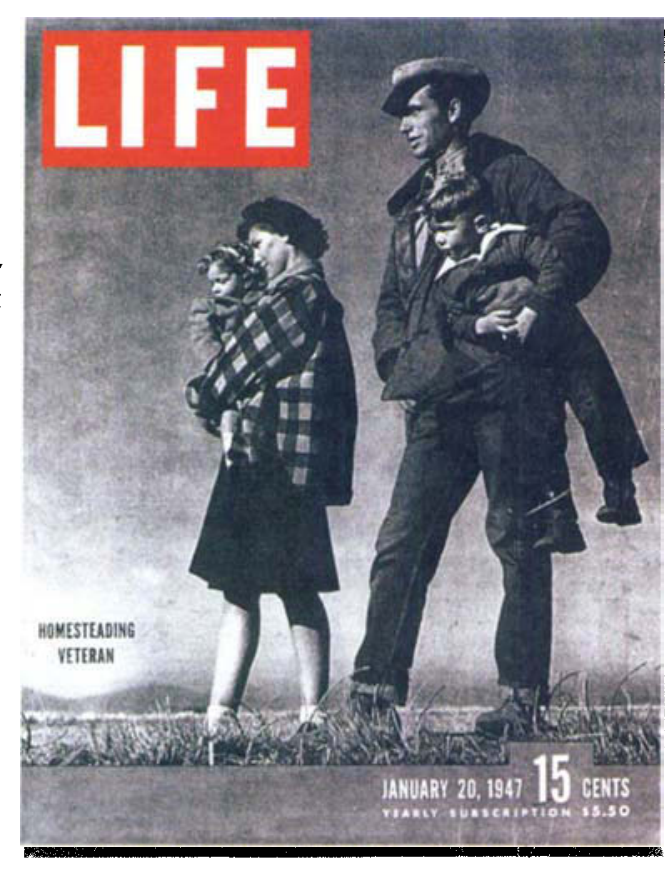

Between 1917 and 1947, thousands of veterans entered a series of lotteries for new agricultural lands created by draining much of Tule Lake under the federal Klamath Project. Life featured homesteader Dale Sprout and his family on a 1947 cover. 


\section{Research update}

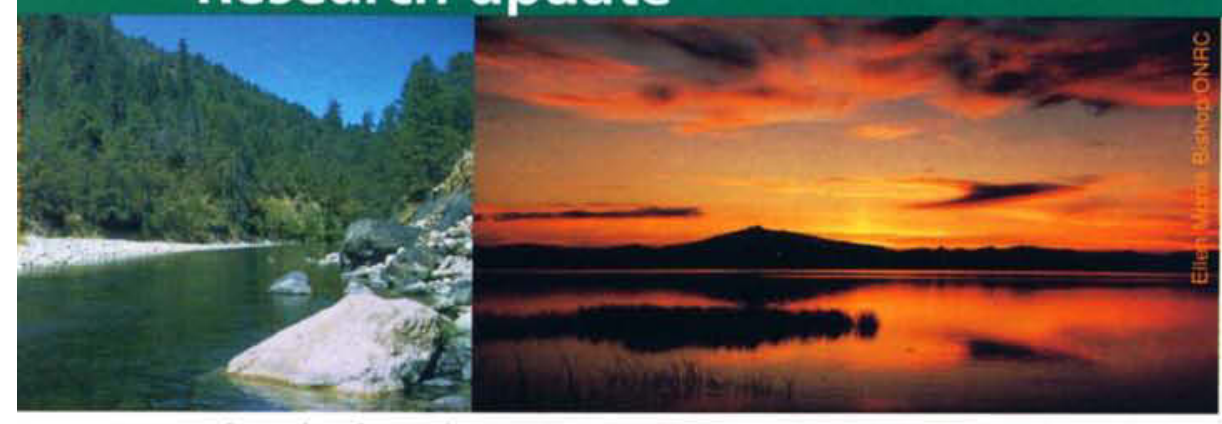

Upper Klamath Lake, right, is home to two native sucker fish; it flows into the Klamath River, left, where coho salmon spawn. Federal regulators must maintain a delicate balance between lake levels and river flows to protect all three endangered fish species.

help juvenile coho salmon. The salmon are highly sensitive to water temperature, and the main water available was warm water from Upper Klamath Lake. Also, increasing flows down river would most likely require the same water that was claimed by FWS to keep lake levels high. "What's good for the suckers may not be good for coho salmon," Moyle says. "It's an ironic problem."

Moyle points out that while there may not have been perfect data to support the decision that was made, under the Endangered Species Act, "agencies are required to err on the side of species when they have doubts." The NAS is scheduled to finalize the review by early 2003 .

$\Delta$

\section{Outreach and community building}

advisors published a booklet on soil moisture monitoring targeted specifically to Klamath Basin growers, which provides a simple method for improving alfalfa and pasture irrigation management.
UC scientists, outreach and extension personnel continue to look for ways to help the Klamath Basin community recover. For example, Kimberly Rodrigues, director of ANR's North Coast and Mountain Region, says that UC and Oregon State University (OSU) are contributing $\$ 40,000$ each to promote community-building in the Klamath Basin.

OSU/UC report. In the difficult months after last April, researchers from OSU and UC collaborated on a baseline assessment of environmental, economic, institutional and social issues in the Klamath Basin. Goals of the forthcoming report include exploring water-allocation alternatives, proposing a research agenda and compiling resources for the region's stakeholders. "Our role is not to affect the outcome, but to provide sciencebased information," Rodrigues says.

"We are trying to provide a rapid assessment of the effects that the decision had, in what we considered a very large vacuum," says OSU professor Thomas Gallagher, who helped coordinate the report.

While OSU took the lead, UC contributors included Carlson, UC Berkeley professor Jeff Romm and graduate researcher George Woodward. In their policy assessment, the latter two wrote: "The problem is not caused by those whose interests are in dispute, but by broader institutional incapacity to create relationships that achieve equitable distributions in scarce times."

Outreach. Ongoing outreach projects have helped educate and inform Klamath Basin residents. In 1993, for example, UC extension advisors conducted training in principled negotiation for 20 of the Basin's agriculture leaders. "Farmer-citizens have to take time out from growing potatoes to advocate," Kaffka says. "Some of them became more effective at advocating their perspective."

UC advisors continue to offer a 4-day short course for ranchers and property owners on water quality in rangeland. ANR recently hired an anadromous fish specialist, Lisa Thompson, to work on inland fish species; she will be offering assistance in the Klamath region. Carlson and UCCE marine advisor James Waldvogel serve on a technical review team for the federal Klamath River Basin Fisheries Task Force,

\begin{abstract}
Kenneth Rykbost, superintendent of Oregon State University's Klamath Experiment Station, and Ronald Voss, UC extension vegetable crops specialist, show off an experimental potato variety harvested at the UC Intermountain Research
\end{abstract} and Extension Center.

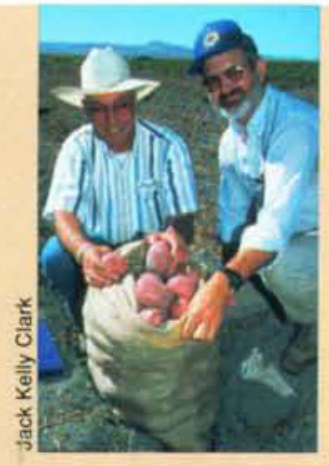

\section{Research delayed, cancelled by drought}

For several decades, the UC Intermountain Research and Extension Center (IREC) has leased about 100 acres from the Tulelake National Wildlife Refuge for agricultural research. But as a result of last year's drought, irrigation was not allowed in the refuge and many research projects were delayed or postponed. Only about 7.5 acres was available for critical research projects at the center's headquarters, irrigated by an emergency well. From 20 to 25 full projects in a normal year, only about a dozen small projects were undertaken in 2001.

For example, UC Davis agronomist Lee Jackson lost a year of data, and several other cereal re- searchers had to curtail their work. Likewise, UC Davis vegetable specialist Ron Voss was able to plant on about half the space he was expecting, which "certainly impacted the quantity and quality of work that we were able to do." He planted $50 \%$ fewer varieties, and since the land at headquarters is not typical of actual growing conditions "the results we got weren't as useful to the growers," Voss says.

When the irrigation water stopped flowing, IREC had actually been in the process of preparing to move research to a new 120 -acre site contiguous to the center. "Ironically, the justification to buy the land was the uncertainty of water availability," IREC superintendent Harry Carlson says. The irrigation cutoff gave center staff time to put in irrigation lines and prepare the site, and the new land is fully populated with field research this year.
$-J . B$. 